\title{
Gaya Pengasuhan Anak Usia Dini pada Suku Dayak Dusun Laek Desa Bengkilu
}

\author{
Wahyuda Dwi Handoko ${ }^{\varpi_{1}}$, Pujiyanti Fauziah ${ }^{2}$ Dimyati $^{3}$ \\ Pendidikan Anak Usia Dini, Universitas Negeri Yogyakarta, Indonesia(1) \\ Pendidikan Luar Sekolah, Universitas Negeri Yogyakarta, Indonesia(1) \\ Pendidikan Olahraga, Universitas Negeri Yogyakarta, Indonesia(1) \\ DOI: 10.31004/obsesi.v6i2.1021
}

\begin{abstract}
Abstrak
Terbatasnya penelitian tentang pengasuhan anak usia dini pada berbagai macam suku yang ada di Indonesia membuat peneliti tertarik untuk mengangkat permasalahan tentang bagaimana pengasuhan anak usia dini pada suku Dayak yang ada di Dusun Laek Desa Bengkilu. Tujuan penelitian ini adalah untuk mendeskripsikan tentang bagaimana Gaya Pengasuhan Anak Usia Dini Pada Suku Dayak Bakati Desa Bengkilu Yang Tinggal di Dusun Laek. Dalam penelitian ini menggunakan pendekatan kualitatif dengan jenis penelitian fenomenologi. Informan dalam penelitian ini terdiri dari ketua adat, purun (orang yang membantu dalam persalinan suku dayak) dan orang tua. Teknik pengumpulan data yang digunakan seperti observasi, wawancara dan dokumentasi. Teknik analisis data yang digunakan adalah model dari Miles dan Huberman. Hasil penelitian menunjukkan bahwa orang tua menggabungkan antara gaya pengasuhan authoritative (otoritatif) dan authoritarian yang diterapkan oleh para orang tua dalam mengasuh anak-anak mereka, sedangkan dalam sikap pengasuhan yang dilakukan orang tua dengan cara menanamkan nilai-nilai kesabaran, kejujuran, patuh, tegas, dan bebas serta menjunjung tinggi hukum adat dalam berperilaku.
\end{abstract}

Kata Kunci: pengasuhan; anak usia dini; suku dayak.

\begin{abstract}
The limited research on early childhood care for various ethnic groups in Indonesia makes researchers interested in raising the issue of how to care for early childhood among the Dayak ethnic groups in Laek Hamlet, Bengkilu Village. The purpose of this study was to describe how the Early Childhood Care Style of the Dayak Bakati Tribe, Bengkilu Village, Who Live in Laek Hamlet. In this study using a qualitative approach with the type of phenomenological research. The informants in this study consisted of traditional leaders, purun (people who assist in childbirth of the Dayak tribe) and parents. Data collection techniques used such as observation, interviews and documentation. The data analysis technique used was a model from Miles and Huberman. The results showed that parents combine authoritative (authoritative) and authoritarian parenting styles that are applied by parents in caring for their children, whereas in parenting attitudes that parents do by instilling the values of patience, honesty, obedience, assertiveness, and free and uphold customary law in behavior.
\end{abstract}

Keywords: parenting; early childhood; dayak tribe.

Copyright (c) 2021 Wahyuda Dwi Handoko, Pujiyanti Fauziah, Dimyati

$\triangle$ Corresponding author:

Email Address : wahyudadwihandoko96@gmail.com (Yogyakarta, Indonesia )

Received 3 January 2021, Accepted 1 April 2020, Published 3 July 2021 


\section{PENDAHULUAN}

Usia dari lahir sampai memasuki pendidikan dasar merupakan suatu masa yang sangat penting dan sekaligus menjadi periode yang kritis dalam setiap tahapan perkembangan anak dalam kehidupan manusia. Dalam usia ini merupakan penentu untuk pembentukan karakter serta kepribadian anak dimana pada masa ini anak pada tahap pertumbuhan dan perkembangan yang sangat pesat, yang sering kita sebut sebagai usia emas (golden age) yang menjadi dasar bagi perkembangan anak (Trianto, 2017: 6). Sehingga periode ini sangat menentukan perkembangan anak pada tahap selanjutnya. Perkembangan anak dalam masa ini adalah suatu kehidupan yang perlu diwaspadai, sehingga dibutuhkannya peran keluarga untuk membantu proses tumbuh dan kembang anak usia dini. Keluarga yang menjadi lembaga pertama untuk anak memiliki peran yang penting dalam upaya mengajarkan pengasuhan yang baik kepada anak-anaknya seperti dalam hal menyelengarakan, mendidik, menjaga, melatih, merawat, membimbing, membantu, memipin dan mengepalai (Lestari, 2016: 36).

Pengasuhan anak merupakan sesuatu yang unik dari budaya dan suatu masyarakat, oleh karenanya pola pengasuhan menjadi berbeda dari suatu masyarakat ke masyarakat yang lain, sesuai dengan sistem nilai dan budaya yang mereka anut. Seperti keluarga yang berperan dalam melakukan pola pengasuhan bagi anak sesuai dengan nilai budaya yang di anut oleh keluarga tersebut (Iriani, 2014: 265). Pola pengasuhan yang terdpat pada keluarga tidak lain merupakan untuk mendidik anak dari lahir hingga terbentuk kepribadian anak. Seperti yang dikatakan Jonn Locke bahwa anak-anak lahir yang di ibaratkan tanpa bekal apapun bagaikan kertas putih yang bersih (Neolaka \& Grace Amialia A., 2017: 158). Maka lingkunganlah yang akan membentuk anak, dalam keterlibatannya orang tua perlu mengenalkan tentang nilainilai yang ada dalam masyarakat. Pada hakikatnya pola pengasuhan atau proses ini merupakan tempat pembentukan watak, kepribadian, dan budi pekerti yang bertujuan untuk membentuk anak dalam berprilaku agar tidak menyimpang sesuai dengan aturan, norma dan nilai yang dianut oleh masyarakat setempat.

Hal ini disebabkan oleh karena bangsa Indonesia merupakan bangsa yang besar, yang terlihat dari jumlah penduduk, wilayah dan keragaman budaya yang mencapai 1.340 suku darai data sensus BPS pada tahun 2010 dan tiap-tiap budaya memmiliki bahasa dabn pola serta karakteristik masing-masing (Na'im \& Syaputra, 2554: 06). Karena banyaknya suku dan budaya yang dimilki oleh bangsa indonesia ini tentulah orang tua memiliki gaya pengasuhan yang berbeda dalam mendidik anaknya sesuai dengan kepercayaan yang dianutnya. Namun pada umumnya menurut Diana Baumrind (Setiono, 2011: 92-93) terdapat tiga jenis pola asuh orang tua yaitu: pola asuh authoritarian, authoritative dan permissive.

Pola asuh authoritarian. Dalam pola asuh authoritarian orang tua membentuk, mengontrol dan mengevaluasi anak dengan menggunakan standar-standar yang diterapkan. Orang tua menekankan kepatuhan dan biasa menggunakan paksaan untuk membentuk tingkah laku yang diinginkan. Orang tua tidak sama sekali memberikan kesempatan dan menerima secara verbal, tetapi orang tua lebih menyukai anak yang menerima apa yang diucapkan oleh orang tua itu dianggap benar.

Orang tua dalam pengasuhan ini memberikan peraturan yang ketat, memberi sanksi serta hukuman pada setiap kesalahan yang anak lakukan, tidak memberi dukungan untuk sikap mandiri dan individualitas pada anak dan orang tua memberibatasan yang tegas sehingga tidak memberikan kesempatan kepada anak untuk mengungkapkan pendapatnya. Orang tua seperti ini cenderung memberikan jarak dan perlakukan yang dingin sehingga orang tua memiliki tingkat kecemasan tinggi, kemampuan untuk berkomunikasi yang buruk dan sangat sulit untuk menunjukkan perasaanya (Santrock, 2015). Anak yang mendapat pola asuh authoritarian ini ceenderung memiliki sifat tidak berani, pemurung dan mudah sekali untuk tersinggung, tidak memiliki kebebasan berpendapat, memiliki rasa takut yang tinggi, selalu merasa cemas, pendiam dan sosial anak cenderung lemah (Pratiwi et al., 2020; Sari, 2020). Jenis pola asuh authoritarian ini juga memiliki kelebihan dalam membentuk karakter 
anak seperti penurut, sedangkan kekurangan dari pola asuh ini mengakibatkan anak tidak percaya diri, kesulitan dalam mengungkapkan pendapat, dan sulit untuk dapat berkomunikasi dengan orang-orang disekitarnya (Hasanah \& Sugito, 2020).

Pola asuh Authoritative, dalam pola asuh ini orang tua cenderung berusaha mengarahkan anak kedalam hal yang lebih baik. Orang tua mendorong terjadinya memberi dan menerima penjelasan secara verbal, memberikan alasan atas pilihan yang diambil dan memperhitungkan apa yang anak sampaikan. Jenis pola asuh ini sangat mengapresiasi setiap keingan anak dan apa pendapat anak (Alviana, 2013). Orang tua pada jenis pola asuh ini memiliki ciri-ciri memberikan pujian dan penghargaan kepada anak, menyediakan waktu untuk bermain dengan anak, memberi perhatian dan kasih sayang serta contoh teladan yang baik bagi anak (Adpriyadi \& Sudarto, 2020). Pola asuh jenis ini juga snagat cocok digunakan untuk membentuk pribadi anak sesuai dengan apa yang menjadi kebutuhan anak (Suteja \& Yusriah, 2017). Ketika orang tua menerapkan pola asuh jenis ini anak akan cenderung mendapatkan kasih sayang yang cukup dari orang tua dan memilik rasa tanggung jawab serta kemandirian yang tinggi (Mirzon Daheri, Juliana, Deriwanto, 2020), hal ini dikarenakan oranngtua memperhatikan setiap kebutuhan anak, mengapresiasi pendapat anak, serta menjelaskan serta konsekuensi tentang sesuatu hal yang baik dan buruk terhadap anaknya (Sofiani et al., 2020).

Pola asuh permissive, dalam pola asuh ini orang tua cenderung tidak pernah memberikan hukuman dan menerima apa yag dilakukan anak tanpa memberikan arahan, pola asuh ini menerapkan kebebasan sepenuhnya kepada anak (Efendhi, 2013). Orang tua tipe ini memberikan tanggapan pada anak dengan cara menerima apapun tindakan yang dilakukan oleh anak, orang tua memberikan tuntutan lebih sedikit terhadap anak sehingga anak kurang memiliki rasa tanggung jawab dalam keluarga. Orang tua tipe ini tidak menekankan aturan secara ketat, cenderung mengacuhkan serta memaafkan semua tingkah laku bermasalah yang anak lakukan, akan tetapi mendorong kemandirian dan individualitas. Pada pola asuh ini Greenwood dalam Efobi \& Nwokolo, (2014) orang tua memiliki ciri-ciri seperti terbuka dalam hal afeksi namun tidak memberi batasan-batasan kepada anak. Orang tua dengan pola asuh permissive ini lebih mementingkan apa yang menjadi kebutuhan yang anak perlukan (Hazizah, 2019).

Dari banyaknya suku di indonesia dan gaya pengasuhan yang telah dijelaskan tadi peneliti tertarik untuk meneliti suku yang ada dikalimantan yaitu suku dayak tentang bagaimana gaya pengasuhan yang dilakukan suku dayak tersebut, karena suku dayak merupakan orang gunung atau pedalaman yang pada dasarnya masih asli sehingga jarang sekali diteliti (Darmadi, 2016).

\section{METODOLOGI}

Penelitian ini menggunakan pendekatan Kualitatif dengan jenis pendekatan penelitian fenomenologi yang merupakan pandangan berfikir yang mendalam untuk menggali suatu kejadian pada setiap individu atau kelompok secara sistematis (Botes, 1996). Penelitian ini dilakukan pada suku Dayak Bakati Desa Bengkilu yang tinggal di dusun Laek Kecamatan Tujuh Belas Kabupaten Bengkayang dengan informan utama yang dipilih dengan cara purposive sampling yang disesuaikan dengan pertimbangan kelayakan dan keperluan dalam penelitian ini. Subjek penelitian ini terdiri dari empat orang yaitu yang pertama ketua adat, Purun (orang yang membantu dalam pesalinan pada suku dayak) dan dua orang tua. Sumber data ini sendiri terdiri dari data primer, yaitu yang berupa data yang diperoleh langsung dari hasil wawancara yang dilakukan kepada narasumber dan informan yang dianggap bisa memberikan informasi yang relevan dan sebenarnya yang terkait permasalahan gaya pengasuhan anak suku dayak Bakati pada saat di lapangan yaitu ketua adat, purun (orang yang membantu dalam pesalinan pada suku dayak) dan orang tua. Data sekunder, yaitu berupa data-data pendukung seperti literatur dan dokumen serta data yang diambil dari Suku Dayak bakati Desa Bengkilu yang tinggal di dusun Laek Kecamatan Tujuh Belas Kabupaten 
Bengkayang. Dalam penelitian ini teknik pengumpulan data yang digunakan adalah dengan menggunakan observasi, wawancara, dan dokumentasi, dalam penelitian ini instrumen pengumpulan data yang digunakan terdiri dari peneliti itu sendiri dengan menggunakan teknik observasi, wawancara serta dokumentasi yang dilakukan kepada empat informan yaitu, ketua adat, purun (orang yang membantu dalam persalinan pada suku dayak) dan orang tua. Sedangkan analisis data yang digunakan dalam penelitian ini menggunakan model dari Miles dan Huberman yang dibagi dalam tiga tahap yaitu reduksi data, penyajian data dan penarikan kesimpulan (Sugiyono, 2014). Sebagai gambaran alur analisis data dapat dilihat pada gambar 1.

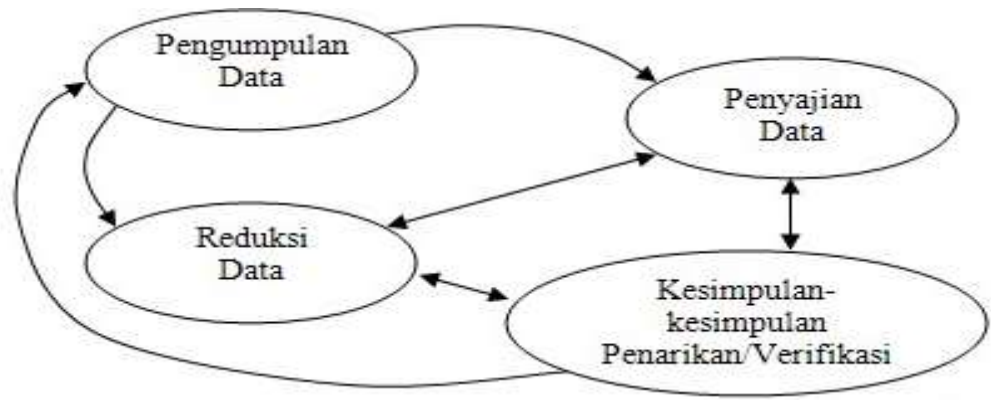

Gambar 1: Alur analisis data

Ketiga tahapan tersebut dilakukan secara berkelanjutan selama penelitian berlangsung. Pada tahap pertama peneliti mereduksi data yang telah dikumpulkan dari empat narasumber untuk memastikan bahwa data sudah sepenuhnya terkumpul dan valid, selanjutnya pada tahap kedua peneliti menyajikan data yang tersusun dalam pola hubungan agar mudah dipahami dari hasil pengumpulan data dan reduksi data, setalah itu pada tahap ketiga peneliti memberikan kesimpulan dari hasil data-data yang telah ada.

\section{HASIL DAN PEMBAHASAN}

Berdasarkan hasil dari penelitian yang telah dilakukan gaya pengasuhan yang diterapkan pada anak usia dini dikeluarga Suku Dayak bakati Desa Bengkilu yang tinggal di dusun Laek Kecamatan Tujuh Belas Kabupaten Bengkayang terlihat menggunakan gaya pengasuhan yang menggabungkan antara gaya pengasuhan authoritative (otoritatif) dan authoritarian yang diterapkan oleh para orang tua dalam mengasuh anak-anak mereka.

Gaya pengasuhan authoritative ini merupakan gaya pengasuhan yang mengajarkan tentang kebebasan kepada anak tetapi anak masih bertanggungjawab atas kebebasan yang telah diberikan oleh orang tuanya. Para orang tua dalam gaya pengasuhan ini masih melakukan pengawasan pada anak-anak mereka baik itu ketika bermain di rumah dan saat bermain dengan teman-teman seusianya yang biasa dilkukan pada sore hari, mereka berkumpul untuk bermain di area depan rumah, bisa di teras maupun dihalaman. Dalam mendidik menggunakan gaya pengasuhan authoritative ini para orang tua mengarahkan perilaku anak secara rasional, dengan cara memberikan penjelasan kepada anak tentang apa yang dimaksud dari aturan-aturan yang telah dibuat. Orang tua cenderung mengarahkan anak untuk mematuhi aturan-aturan yang telah dibuat dengan kesadaran diri sendiri pada anak. Pada hal lainnya orang tua bersikap cekatan terhadap apa yang menjadi kebutuhan dan pemikiran anak. Dari model pengasuhan authoritative (otoritatif) ini anak diajarkan untuk bersikap tidak tertutup kepada orang tua. Anak mendapatkan kesempatan untuk menyampaikan apa saja yang anak rasakan kepada orang tuanya, seperti ketika anak sedang mendapat masalah atau bertengkar dengan temannya anak akan cenderung terbuka menceritakan permasalahan yang anak alami kepada orang tua. Dari hal tersebut selaras dengan hasil penelitian yang dilakukan oleh Wulandari ia menyatakan bahwa dalam pola 
asuh orang tua sebaiknya menerapkan pola asuh yang sesuai dengan situasi dan kondisi serta melihat kebutuhan dan perkembangan dari setiap anak (Wulandari R, 2016).

Orang tua dalam gaya pengasuhan ini memberikan kebebasan kepada anaknya untuk menentukan dan melakukan apa yang ingin anak lakukan dan dalam gaya pengasuhan ini orang tua memberi apresiasi dari setiap usaha dan hasil yang dilakukan oleh anak, serta diharapkan anak-anak nantinya akan dapat termotivasi menuju arah yang lebih baik.

Salah seorang informan mengemukakan dalam pengasuhan yang dilakukan kepada anak, mereka mengkomunikasikannya dengan baik. Anak diberikan kebebasan namun orang tua tetap memberikan pengawasan terhadap anak. Contoh ketika anak sedang bermain dengan temannya maka orang tua akan tetap mengawasi dan apabila sudah sore dan waktu untuk pulang dan anak belum juga pulang maka orang tua mereka akan mencari anaknya dan mengajaknya pulang. Setelah anak pulang pada jam makan malam oarangtua menyempatkan untuk mengobrol dengan anak-anaknya dan orang tua menanyakan tentang apa saja yang anak lakukan seharian ini. Tentu saja anak menjawab pertanyaan yang ditanyakan oleh orangtunya dan anak pun bersikap terbuka dan menceritakan apasaja kegiatan yang anak lakukan seharian ini. Ketika dalam mengobrol pada jam malam tersebut saat anak menceritakan kegiatan yang ia lakukan seharian ini dan terjadi suatu masalah, orang tua memberikan penjelasan dan nasihat kepada anaknya agar sang anak memiliki pemahaman dan dapat menyelesaikan masalah yang anak hadapi tadi. Ketika orang tua memberikan nasihat atau pemahaman tadi orang tua juga memberikan contoh, misal ketika anak suka bermain dan susah untuk belajar, orang tua dapat membimbing dan mengarahkan anak untuk belajar dan biasanya juga dengan menceritakan orang-orang yang berperilaku baik dan ranjin belajar sehingga bisa menjadi sukses dalam hal pendidikan. Yang harapan nantinya anaknya kelak bisa mencontoh perilaku tersebut sehingga anak bisa menjadi sukses dan berpendidikan tinggi dengan dasar dan bekal atau wawasan yang baik bagi anak untuk mencapai cita-citanya kelak.

Harapan yang orang tua inginkan dalam pendidikan yang tinggi untuk anaknya ini selaras dengan hasil penelitian yang telah dilakukan oleh Adawiah ia mengatakan bahwasannya pemahaman orang tua dalam hal pendidikan bagi anak pada masyarakat suku Dayak di Kecamatan Halong masuk dalam kriteria baik. Orang tua pada umumnya memahami bahwasannya pendidikan itu merupakan suatuhal yang sangat penting bagi anak (Adawiah, 2017). Hal ini dapat kita ketahui dari seluruh jawaban informan yang mengatakan pada dasarnya orang tua ingin agar anak-anaknya nanti dapat sekolah dengan setinggitingginya. Dari pendidikan yang tinggi ini orang tua mengharpkan anak-anak mereka menjadi seorang yang berjaya dikehidupannya kelak dan hal ini sebaiknya dilakukan dari sedini mungkin karena pada masa usia dini anak-anak sangat mudah untuk dibentuk pola pemikirannya dan bisa dilakukan dengan memberikan bimbingan, nasihat, araham dan mendukung apa yang anak lakukan selama kegiatan yang dilakukan anak bisa bermanfaat baginya dan tidak membahayakan serta merugikan anak, hal ini sangat penting untuk dilakukan dengan baik melihat dapaknya yang begitu besar bagi anak agar masa depan mereka menjadi lebih baik. Dalam hal ini keluarga memiliki peranan yang sangat besar dalam menanamkan pola pikir yang baik terhadap anak dikarenakan keluarga merupakan pendidikan informal pertama bagi anak.

Selanjutnya dalam gaya pengasuhan authoritarian adalah gaya pengasuhan yang dilakukan oleh orang tua dengan berusaha membentuk, mengontrol, mengutamakan kepatuhan dan menggunakan paksaan dalam membentuk tingkah laku yag diinginkan. Namun dalam gaya pengasuhan ini orang tua hanya melakukan itu untuk memberikan tindakan kepada anak agar anak menurut dan agar anak menjadi yang lebih baik, namun tindakan yang dilakukan oleh orang tua pada gaya pengasuhan ini masih dalam batasan yang wajar tanpa memberikan efek yang berlebihan seperti cidera fisik yang parah.

Seperti yang dikatakan oleh salahsatu informan pada saat diwawancarai, orang tua bersikap mengontrol anak ketika anak tersebut menginginkan sesuatu yang dapat 
membahayakan anak tersebut, dengan contoh ketika anak senang bermain di sungai, karena topografi di kabupaten bengkayang yang di aliri oleh 3 aliran sungai (Muhrotien, 2012: 34), yang menjadikan anak-anak sering bermain di sungai, hal ini tentu menjadi suatu kekhawatiran bagi orang tua yang mengakibatkan orang tua cenderung mengontrol anaknya agar jangan bermain di sungai, namun orang tua disini juga memberikan solusi atau nasihat kepada anaknya dengan memberi pengertian seperti boleh bermain di suingai ketika ada keluarga atau orang dewasa yang dapat di andalkan untuk menjaga anak ketika terjadi sesuatu hal yang tidak diinginkan, akan tetapi ketika anak tidak mau mendengarkan apa yang orang tua jelaskan dan sampaikan tadi, oarangtua cenderung memberikan tindakan menghukum berupa hukuman fisik seperti di cubit, di jewer telinganya dan bahkan bisa dipukul dengan kayu kecil untuk memberikan efek jera dan menurut dari apa yang dikatakan oleh orang tua tadi.

Tetapi dalam pemberian hukuman ini orang tua tidak memberikan hukuman fisik yang sampai membuat anak memiliki cidera yang fatal, hanya saja orang tua memberikan hukuman fisik itu seperti mencubitnya tidak dengan keras dan saat memukul anakpun tidak begitu kuat. Setelah orang tua melakukan hukuman fisik tersebut orang tua juga merasakan penyesalan kenapa sampai harus memberikan hukuman fisik kepada anak, setelah orang tua memberikan hukuman fisik tersebut orang tua akan meminta maaf kepada anak karena telah memberikan hukuman fisik serta memberikan pengertian dan penjelasan bahwasannya orang tua melakukan itu semua adalah tidak disengaja dikarenakan anak tidak mau menurut dan karena itu orang tua melakukan hukuman fisik tersebut.

Dari informan selanjutnya yaitu ketua adat yang tinggal di dusun laek mengatakan bahwa dalam mengasuh anak beliau memasukkan ajaran untuk bersikap sopan santun dan menghormati orang lain yang dihubungkan dengan hukum adat sehingga tiap tingkah laku dan perbuatan harus mengingat hukum adat. Dalam pelaksanaannya masyarakat sering menyebutnya dengan kata "ngajar" ketika dalam penerapannya ada anak yang melakukan kesalahan dalam bertingkahlaku harus berpegang pada hukum adat yang berlaku di desa, dan mengajarkan kepada anak-anak bagaimana cara berperilaku misalkan saja ketika masuk kedalam rumah harus mengucapkan salam atau permisi, hal ini dilakukan untuk menghormati orang yang berada didalam rumah. Dari hal tersebut dapat terlihat bahwasannya keluarga Suku Dayak Bakati Desa Bengkilu yang tinggal di dusun Laek sangat menjunjung tinggi niali-nali dari adat-istiadat yang ada. Penerapan tentang nilai dari adatistiadat ini dilakukan oleh masyarakat dan orang tua dalam kegiatan kehidupan sehari-hari termasuk dalam hal pengasuhan kepada anak usia dini.

\section{Sikap Pengasuhan yang Dilakukan Orang Tua Suku Dayak Bakati yang Tinggal di Dusun Laek}

Sikap pengasuhan yang diterapkan kepada anak usia dini pada keluarga suku dayak Bakati tampak seperti yang dikatakan oleh ketua adat dan purun (dukun beranak kampung) serta terlihat dari penerapan yang dilakukan para informan bahwasannya dalam mengasuh anak harus menanamkan nilai kesabaran, kejujuran, patuh, tegas dan kebebasan. Hal ini selaras dengan hasil penelitian yang telah dilakukan oleh Fransiska yang menyatakan bahwa Keluarga Dayak Desa yang Tinggal di Rumah Betang Ensaid Panjang dalam pengasuhan anak usia dini menjujung tinggi nilai Kesabaran, Kejujuran, Kepatuhan, Ketegasan dan Kebebasan (Fransiska \& Suparno, 2019).

Nilai-nalai yang diterapkan dalam kehidupan sehari-hari ini memberikan makna atau penjelasan sebagai berikut: Kesabaran, nilai kesabaran ini dapat dilakukan orang tua dengan cara mengajarkan anak dengan penuh rasa sabar tidak mudah marah, emosi dan lain sebagainya dengan harapan yang diinginkan oleh orang tua ketika dikemudian hari nanti anak bisa berperilaku yang baik sesuai dengan nilai kesabaran. Seperti halnya ketika anak bermain dengan temannya ia tidak mudah marah dan memukul temannya pada saat bermain hal ini menjunjung tinggi nilai kesabaran dan "ngajar" yang orang tua ajarkan kepada anak. 
Dalam menerapkan nilai kesabaran ini harus dilakukan dengan komunikasi yang baik antara orang tua dan anak, karena hal ini dapat menjadi penyebab dalam mendidik anak dengan penuh rasa sabar. Komunikasi yang baik dapat dilakukan sedini mungkin dengan harapan agar anak memahami nilai kesabaran dalam bertingkahlaku dikehidupan sehari-hari. Hal ini selaras dengan hasil penelitian Jatmikowati ia menyatakan bahwa komunikasi yang terjalin antara anak dan orang tua berlangsung secara terbuka dapat membuat anak merasa lebih diterima. Anak mendapat keberanian dalam menentukan pilihan yang ia inginkan, sedangkan orang tua sering mengatakan harapan yang apaadanya sesuai dengan kemampuan yang dimiliki oleh anak-anaknya, dengan demikian nilai positif yang ada pada anak dapat dibangun dengan sendirinya (Jatmikowati, 2018: 13).

Kejujuran, nilai kejujuran juga ditanamankan dalam pengasuhan anak yang dilakukan dengan harapan anak memiliki sifat yang jujur hingga dewasa kelak. Nilai kejujuran ini dapat terlihat ketika anak tidak diperbolehkan untuk berbohong dan mengambil suatu barang yang bukan miliknya atau hak yang menjadi orang lain. Ketika anak mengambil barang yang bukan miliknya akan dikenakan hukum adat. Hukum adat disini melihat ringan beratnya kerugian yang ditimbulkan, jika kerugian yang ditimbulkan itu ringan hanya diberikan hukuman adat mengganti benda yang dicuri dan membayar denda adat berupa membayar alang, jika dinominalkan dengan rupiah sejumlah Rp150.000,00. Dengan adanya hukuman adat ini diharapkan nilai kejujuran dapat diajarkan pada anak sejak sedini mungkin ini diharapkan agar anak dapat memiliki sikap yang jujur dan tidak berbohong, sehingga dalam kehidupan anak kelak ia akan selalu bersikap jujur dalam situasi dan kondisi apapun. Menanamkan sikap kejujuran ini harus dilakukan melalui perkataan dan perbuatannya. Dalam hal ini orang tua memiliki peran penting yaitu sebagai panutan bagi anak dan perlunya menanamkan nilai kejujuran dalam kehidupan sehari-hari ini dikarenakan anak akan belajar melalui apa yang anak lihat dalam kehidupan sehari-hari anak, yang terutama terlihat dari tindan tingkahlaku orang tuanya sendiri. Hal ini sesuai dengan hasil penelitian yang dilakukan oleh Inten bahwasannya dalam menanamkan nilai kejujuran kepada anak yang dilakukan orang tua sangatlah penting. Nilai kejujuran ini dapat dilakukan orang tua dengan menunjukkan sikap yang tidak berbohong seperti ketika orang tua berjanji akan memberikan hadiah kepada anak, dan orang tua menepati janji tersebut seingga menjadi suatu perilaku yang bermakna bagi anak (Inten, 2017). Tidak hanya itu saja, dalam menanamkan nilai kejujuran pada anak ini dapat dilakukan pada saat anak bermain dengan teman-teman sebayanya seperti ketika anak mengambil mainan temannya tanpa meminta izin kepada temannya tersebut, anak diajarkan untuk mengakui kesalahan apa yang telah ia lakukan dan berkata jujur dan mengembalikan mainan yang telah diambil anak serta anak di ajarkan untuk meminta maaf kepada teman yang barangnya diambil tadi.

Patuh, nilai patuh yang dimasksud dalam hal ini adalah menuruti apa yang dikatakan oleh kedua orang tuanya yang hal ini dilakukan bagi kebaikan anak-anak mereka. Nilai patuh ini diajarkan oleh orang tua dengan cara meminta anak untuk membantu orang tua dan belajar. Melalui nilai patuh yang diajarkan kepada anak harapan orang tua tentang anak agar dapat mematuhi apa yang menjadi keinginan orang tua demi kebaikan anak dan nilai kepatuhan ini diajarkan sedini mungkin dengan harapan anak dapat melakukannya dengan penuh keiklasan tanpa ada paksaan dari siapapun. Nilai patuh ini juga bermakna mematuhi segala hukum adat yang berlaku pada masyarakat Suku Dayak Bakati dari setiap aturan hukum adat yang ada misalnya saja dalam hal berperilaku harus sopan santun jujur agar tidak merugikan orang lain, dan ketika ada yang melanggar hal tersebut maka akan dikenakan hukum adat bisa berupa denda mambayar alang, dan denda lainnya yang tertera pada hukum adat seperti yang telah disampaikan oleh ketua adat yang tinggal di dusun laek, hal ini dikarenakan hukum adat merupakan suatu pedoman bagi masyarakat untuk bertingkahlaku dan untuk menyelesaikan masalah yang ada dalam kehidupan sehari-hari yang terjadi pada masyarakat. Dikarenakan nilai patuh ini bermakna mematuhi hukum adat sebagai pedoman hidup masyarakat yang telah mendarah daging bagi masyarakat, hal ini menjadikan hukum 
adat untuk dipatuhi dan dijalankan tanpa beban bagi anak dan anggota masyarakat yang tinggal di Desa Bengkilu Dusun laek.

Tegas, nilai tegas dalam hal ini memiliki artian bahwa setiap anak harus memiliki sifat yang tidak mudah dihasut dalam pendiriannya. Niali tegas ini dapat terlihat pada saat anak dan masyarakat dalam kehidupan sosial sehari-hari yang dilakukan dengan teman maupun dengan orang yang lebih tua dari merka, anak menunjukkan sikap sopan santun terhadap orang tua, sebaliknya ketika anak menunjukkan tingkah laku yang tidak baik orang tua akan menegur anak dengan tegas dan bahkan bisa memberikan hukuman yang sesuai tanpa melewati batas yang dapat menciderai anak. Nilai tegas sangat penting untuk ditanamkan sedini mungkin karena menajarkan kepada anak tentang apa pilihan apa yang ia inginkan kokoh pada pendirian anak. Sikap ini sering juga kita sebut dengan kata asertif yang bermakna juga suatu kemampuan untuk mengkomunikasikan apa yang diinginkan. Sikap asertif ini perlu untuk dikenalkan kepada anak seiring dengan berkembangnya kemampuan berbahasa pada anak, agar anak dapat bertindak sesui dengan apa yang anak inginkan, yang akan membuat anak merasa tidak tertekan karena keinginannya dapat tersampaikan sehingga dapat menumbuhkan rasa percaya diri anak (Muthmainnah, 2015). Sehingga menjadi penting bahwa nilai ketegasan untuk diajarkan kepada anak dalam kehidupan sehari-hari. Orang tua menanamkan nilai tegas kepada anak dengan harapan anak dapat memiliki sifat tegas dalam memberikan suatu keputusan yang diambil oleh anak, hal ini terlihat ketika anak diajak temannya unutuk mengambil barang orang lain seperti mengambil buah milik tetangga tanpa meminta izin terlebih dahulu anak dapat dengan tegas mengatakan itu perbuatan yang tidak baik, sebaiknya meminta izin terlebih dahulu kepada pemilik buah tersebut. Orang tua menerapkan nilai tegas ini bukan untuk mengekang anak akantetapi orang tua ingin dalam kehidupannya anak dapat dengan tegas memilih perilaku yang baik. Ketika anak dari kecil sudah diajarkan dan memahami sikap tegas ini anak akan lebih berani dalam menentukan keputusan apa yang akan diambil olehnya, karena anak sudah faham tentang bagaimana perbuatan yang baik untuk dirinya dan perbuatan mana yang tidak baik untuknya.

Kebebasan, nilai kebebasan disini merupakan bagaimana orang tua memberikan kebebasan dalam memilih apa yang anak inginkan akan tetapi orang tua masih senantiasa memantau kegiatan anak dan mengarahkannya dalam kegiatan yang baik untuk dilakukan anak. Orang tua di Suku Dayak Bakati yang tinggal di Dusun Laek Desa Bengkilu cenderung memberikan kebebasan dalam hal apa yang anak inginkan tetapi orang tua masih memperhatikan setiap perilaku yang dilakukan oleh anak-anak mereka. Dalam nilai kebebasan ini rangtua menjadi sosok sahabat untuk anak, sehingga ketika orang tua bisa menjadi sahabat bagi anak, anak dapat menyampaikan apa yang menjadi keinginnya tanpa adanya rasa takut. Hal ini dapat kita lihat dari hasil wawancara salah satu informan yang memiliki anak berusia 5,8 tahun yang dimana ia menceritakan meskipun anaknya terbilang masih kecil ia sudah memberikan kebebasan kepada anaknya untuk melakukan kegiatan yang anak inginkan, seperti ketika anak diajak orang tua ke kebun dikarenakan pekerjaan orang tua sebagai petani dan tidak ada yang menjaga anaknya tersebut, anak ingin di beri kebebasan untuk bermain di area sekitaran kebun, biasanya anak akan bermain tanah, atau bermain dengan daun dan mengeksplor apa saja benda yang dianggap menarik bagi anak dan orang tua dalam hal ini masih tetap memantau anak walupun dalam kejauhan agar ketika anak dalam keadaan bahaya anak bisa segera diselamatkan oleh orang tuanya sehingga anak dalam keadaan aman dari gangguan apapun. Orang tua juga seharusnya mendukung dan memfasilitasi kegiatan bermain anak (Fauziddin et al., 2021). Kebebasan yang orang tua berikan kepada anaknya pada saat bermain merupakan suatu bentuk rasa kepedulian dari orang tua kepada tumbuh kembang anak, karena ketika anak bermain berbagai aspek perkembangan anak akan terstimulus.

Seperti yang kita ketahui bahwa dunia anak adalah bermain dan bermain itu merupakan pekerjaan anak yang dimana pada saat bermain dapat membantu anak dalam mencapai segala aspek perkembangan anak serta fisik dan mental secara optimal (Alfiadi, 
2016). Melalui bermain ini lah, seluruh pancaindra anak akan berkembang dan tentunya dalam hal ini orang tua juga memiliki peran dalam memberikan umpan balik dalam setiap perkembangan anak agar dari setiap perkembangan anak dapat terpantau dan berkembang dengan baik sesui harapan yang orang tua inginkan kepada anaknya untuk bekal persiapan dimasa yang akan datang bagi sang anak.

\section{SIMPULAN}

Gaya pengasuhan dengan menggabungkan antara gaya pengasuhan authoritative (otoritatif) dan authoritarian yang diterapkan oleh para orang tua dalam mengasuh anak, serta dalam kehidupan sehari-hari orang tua pada Suku Dayak Bakati yang Tinggal di Dusun Laek menanamkan nilai-nilai kesabaran, kejujuran, patuh, tegas dan bebas kepada anaknya dan masih menjujung tinggi hukum adat yang berlaku pada Suku Dayak Bakati yang tinggal di Dusun Laek dalam berperilaku.

\section{UCAPAN TERIMA KASIH}

Peneliti mengucapkan terimakasih kepada semua pihak yang berperan penting dalam penelitian ini, terutama kepada kedua orang tua dan pembimbing (Dr. Puji Yanti Fauziah, M.Pd dan Prof. Dr. Dimyati, M.Si) yang telah memberikan semangat dan dukungan sampai penelitian ini selesai, tidak lupa juga peneliti uacapkan terimakasih kepada ketua adat, purun dan informan yang telah meluangkan waktu untuk berpartisipasi dalam penelitian ini.

\section{DAFTAR PUSTAKA}

Adawiah, R. (2017). Pola Asuh Orang Tua Dan Implikasinya Terhadap Pendidikan Anak: Studi Pada Masyarakat Dayak Di Kecamatan Halong Kabupaten Balangan. Jurnal Pendidikan Kewarganegaraan, 7(1), 33-48.

Adpriyadi, \& Sudarto. (2020). Pola Asuh Demokratis Orang Tua Dalam Pengembangan Potensi Diri Dan Karakter Anak Usia Dini. VOX EDUKASI: Jurnal Ilmiah Ilmu Pendidikan, Volume 11. https:/ / doi.org/10.31932/ve.v11i1.572

Alfiadi. (2016). Bermain dan Permainan Bagi Anak Usia Dini. Itqan: Jurnal Ilmu-ilmu Pendidikan, Vol. VII,

Botes, A. (1996). Qualitative research in nursing - Advancing the humanistic imperative. Health SA Gesondheid, 1(1). https:// doi.org/10.4102/hsag.v1i1.304

Darmadi, H. (2016). Dayak Asal-usul dan Penyebaran Di Bumi Borbeo (1). SOSIAL HORIZON: Jurnal Pendidikan Sosial, Vol. 3, No.

Efendhi, F. (2013). Pengaruh Pola Asuh Orang Tua Terhadap KemandirianDalam Belajar Siswa. Jurnal Ilmiah Pendidikan Bimbingan Dan Konseling, 1(3).

Efobi A, \& Nwokolo C. (2014). Relationship between Parenting Styles and Tendency to Bullying Behaviour among Adolescents. Journal of Education \& Human Development, 3(1), 507-521.

Fauziddin, M., Mayasari, D., \& Rizki, L. M. (2021). Effective Learning for Early Childhood during Global Pandemic. Al-Ishlah: Jurnal Pendidikan, 13(1).

Fransiska, F., \& Suparno, S. (2019). Pengasuhan Anak Usia Dini Pada Keluarga Dayak Desa Di Rumah Betang Ensaid Panjang. Jurnal Golden Age, 3(02), 95. https:// doi.org/10.29408/goldenage.v3i02.1655

Hasanah, N., \& Sugito, S. (2020). Analisis Pola Asuh Orang Tua terhadap Keterlambatan Bicara pada Anak Usia Dini. Jurnal Obsesi : Jurnal Pendidikan Anak Usia Dini, 4(2), 913. https:// doi.org/10.31004/obsesi.v4i2.456

Hazizah, N. (2019). Permissive Parenting Effect toward Emotional Development of Early Childhood. KOLOKIUM: Jurnal Pendidikan Luar Sekolah, 7(1), 1-8. https://doi.org/10.24036/kolokium-pls.v7i1.17 
Inten, D. N. (2017). Penanaman Kejujuran Pada Anak Dalam Keluarga. FamilyEdu, 3(1), 3545. https://doi.org/10.29313/ga.v1i1.2689

Iriani. (2014). Pola pengasuhan anak pada suku tolaki di sulawesi tenggara. Walasuji, 5(2), 265276.

Jatmikowati, T. E. (2018). Efektifitas Komunikasi Orang Tua Terhadap Kepribadian Intrapersonal Anak. Pedagogi : Jurnal Anak Usia Dini dan Pendidikan Anak Usia Dini, 4(2), 1. https://doi.org/10.30651/pedagogi.v4i2.1936

Lestari, S. (2016). Psikologi Keluarga Penanaman Nilai \& Penanganan Konflik dalam Keluarga. Kencana. Jakarta: Prenadamedia Group.

Mirzon Daheri, Juliana, Deriwanto, A. D. A. (2020). Jurnal basicedu. Jurnal basicedu, 3(2), 524532. https:// doi.org/10.31004/basicedu.v4i4.445

Muhrotien, A. (2012). Rekonstruksi Identitas Dayak. Yogykarta: TICI Publications.

Muthmainnah, -. (2015). Melatih Asertivitas Pada Anak Usia Dini. Jurnal Pendidikan Anak, 2(1), 249-257. https://doi.org/10.21831/jpa.v2i1.3035

Na'im, A., \& Syaputra, H. (2554). Kewarganegaraan, Suku Bnagsa, Agama, dan Bahasa Seharihari Penduduk Indonesia (Hasil Sensus Penduduk 2010). Jakarta: Badan Pusat statistik. Diambil dari http:/ / library1.nida.ac.th/termpaper6/sd/2554/19755.pdf

Neolaka, A., \& Grace Amialia A. (2017). Landasan Pendidikan Dasar Pengenalan Diri Sendiri Menuju Perubahan Hidup. Depok: Kencana.

Pratiwi, K. E., Haniarti, \& Usman. (2020). Pengaruh Pola Asuh Orang Tua Terhadap Kemandirian Anak di SD Negeri 38 Kota Pare Pare. Jurnal Ilmiah Manusia Dan Kesehatan, VOL3 NO 1. https:// doi.org/10.31850/makes.v3i1.288

Santrock, J. W. (2015). Psikologi Pendidikan. Jakarta: Salemba Humanika.

Sari, C. W. P. (2020). Pengaruh Pola Asuh Otoriter Orang Tua Bagi Kehidupan Sosial Anak. $\begin{array}{llll}\text { Jurnal Pendidikan } \quad \text { dan } & \text { 87-93. }\end{array}$ https://doi.org/10.24042/ajipaud.v2i2.4669

Setiono, K. (2011). Psikologi Keluarga. Bandung: PT ALUMNI.

Sofiani, I. K., Mufika, T., \& Mufaro'ah, M. (2020). Bias Gender dalam Pola Asuh Orangtua pada Anak Usia Dini. Jurnal Obsesi: Jurnal Pendidikan Anak Usia Dini, 4(2), 766. https://doi.org/10.31004/obsesi.v4i2.300

Sugiyono. (2014). Metode Penelitian Pendidikan pendekatan Kuantitatif, Kualitatif dan R\&D. In Metode Penelitian Pendidikan (Pendekatan Kuantitatif, Kualitatif dan R\&D) (Bandung). Alfabeta.

Suteja, J., \& Yusriah, Y. (2017). Dampak Pola Asuh Orang Tua Terhadap Perkembangan SosialEmosional Anak. AWLADY Jurnal Pendidikan Anak, Vol. 3 No. https://doi.org/10.24235/awlady.v3i1.1331

Trianto. (2017). Pembelajaran Terpadu (Konsep, Strategi, dan Implementasinya dalam Kurikulum Tingkat Satuan Pendidikan). Jakarta: Bumi Aksara.

Wulandari R. (2016). Pola asuh anak usia dini (studi kasus pada orang tua yang mengikuti program bina keluarga balita $(\mathrm{BKB})$ di kelurahan kutoharjo kabupaten purworejo. Universitas Negeri Semarang, 147, 11-40. 